\title{
Apelin Increases Airway Responsiveness and Inflammation in a Mouse Model of Asthma
}

\author{
Armaan Siddiquee, Deven Narke, Mangesh Kurade, Kshiti Dholakia and Dovenia S Ponnoth* \\ Division of Pharmaceutical Sciences, Long Island University, USA
}

Submission: March 05, 2018; Published: March 23, 2018

*Corresponding author: Dovenia S Ponnoth, Division of Pharmaceutical Sciences, Arnold \& Marie Schwartz College of Pharmacy, Long Island University Brooklyn, New York, USA, Tel: (718) 780-4079; Fax: (718)780-4586; Email: Dovenia.Ponnoth@liu.edu

\begin{abstract}
There is evidence that inflammatory exacerbations in asthma may be mediated by specific endogenous peptides. Apelin, an endogenous hypotensive and angiogenic peptide, is increased in atopic asthma. However, it is unclear how apelin affects allergic inflammation observed in asthma. We studied the role of exogenously administered apelin in airway hyper reactivity and inflammation in allergic mice. Mice were

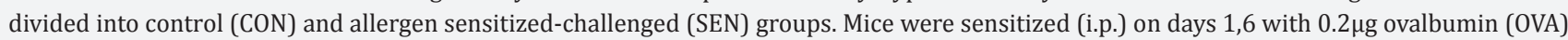
followed by $5 \%$ OVA aerosol challenges on days $11-13$. Apelin was given i.p. as a single bolus dose $(4 \mathrm{mg} / \mathrm{kg}$ ) on day 14 to SEN mice. Whole body plethysmography (measuring airway responsiveness as enhanced pause, Penh) and bronchoalveolar lavage (BAL) studies were then performed. Airway responsiveness to MCh (48mg/ml) was highest in SEN+APELIN group (126.43 \pm 30.61 vs. $36.95 \pm 11.44 \%$ in SEN, $p<0.05, n=3)$. Differential BAL cell analysis showed that treatment with apelin increased eosinophils $(68.67 \pm 1.86 \%$ in SEN vs $80.67 \pm 1.20 \%$ in SEN $+A P E L I N$, p<0.05) and neutrophils $(8.33 \pm 0.88 \%$ in SEN vs $13.33 \pm 0.88 \%$ in SEN+APELIN, $\mathrm{p}<0.05)$ in sensitized mice, thus potentiating the allergic inflammation. Although further studies are needed to evaluate detailed cellular mechanisms, the role of apelin and apelinergic system appears to be proinflammatory in this model of asthma.
\end{abstract}

Keywords: Apelin; Asthma; Airway responsiveness; Airway inflammation

Abbreviations: IP: Intra-Peritoneal; SEN: Sensitized; CON: Control; PENH: Enhanced Pause

\section{Introduction}

Apelin, also termed as APLN, is a peptide encoded by the apelin gene [1]. The apelinergic system comprises of apelin and its G-protein coupled receptor APJ [2] which was originally identified by O'Dowd et al. [3]. For long, APJ, a receptor sharing similarities with the angiotensin II receptor (AT1R), was labeled an orphan GPCR since it was not activated by any of the known ligands [3]. The identification of the cognate ligand apelin stripped the orphan title of the human apelin receptor (APJ) and opened up possibilities leading to novel biological studies. Apelin exists as a 36 amino acid peptide (apelin-36), along with other isoforms including apelin-17, apelin-13, apelin- 28,apelin-31 and apelin 12 [3-6] Apelin and APJ are found abundantly in various tissues of organs such as heart, lung, stomach, kidneys, in most parts of the brain and adipose tissue $[4,5,7,8]$.

Over the years it has been reported that apelin possesses hypotensive properties [9-11] along with a broad range of physiological effects, however the main physiological function of apelin and its receptor APJ remains unclear to this date. This may be due to the different binding properties of different sized apelin isoforms to its receptors [12]. Apelin is believed to exhibit regulatory effects on the cardiovascular system, energy metabolism, fluid homeostasis, inflammation (antiinflammatory) and angiogenesis [6,2].

The APJ gene and its regulation has not yet been fully understood and the role of apelin and APJ gene in asthma is a justifiable new aspect to be looked into since acute and repeated stress has been linked to the up- regulation of the APJ gene [13]. Hence the aim of this study was to understand the role of apelin in our mouse model of asthma [14]. An unrestrained whole body plethysmograph (Buxco electronics, Troy, NY) was used to assess the airway hyper-responsiveness by measuring the respiratory air flow pressure curves of individual mice to different concentrations of methacholine (MCh).

\section{Conclusion}

The effect of apelin on airway responsiveness was measured using methacholine $(\mathrm{MCh})$ by whole body plethysmography. Data was obtained as enhanced pause (Penh) based on the protocol described by Ponnoth et al. [15]. Penh correlates to airway obstruction, and higher the Penh values, greater is 
the airway obstruction. Inhalation of MCh exhibited a dosedependent increase in bronchoconstrictor responses with apelin treatment increasing the response in $(126.43 \pm 30.61$ vs. $36.95 \pm 11.44 \%$ in $\mathrm{SEN}, \mathrm{p}<0.05, \mathrm{n}=3$ ). These data indicate apelin increased bronchoconstriction induced by MCh in asthmatic mice. Our next experiment consisted of studying the cellular content in the bronchoalveolar lavage (BAL) fluid taken from the lungs of the experimental mice to determine the effect of apelin in the recruitment of inflammatory cells in the asthmatic mice. Differential cell analysis showed that sensitized mice had significant inflammation compared to controls, and apelin further increased the inflammation. The differential count studies were done 24 hours after the airway responsiveness studies. Cell counts for eosinophils, macrophages and neutrophils were obtained. Differential BAL cell analysis showed that treatment with apelin increased eosinophils $(68.67 \pm 1.86 \%$ in SEN vs $80.67 \pm 1.20 \%$ in SEN+APELIN, $\mathrm{p}<0.05$ ) and neutrophils $(8.33 \pm 0.88 \%$ in SEN vs $13.33 \pm 0.88 \%$ in SEN+APELIN, $\mathrm{p}<0.05)$ in sensitized mice, thus potentiating the allergic inflammation. Thus our major finding for this study is that although apelin has been shown to be anti-inflammatory in certain conditions, it appears to have a pro-inflammatory role in allergic study. Airway hyper responsiveness correlated to eosinophilia increased with apelin. Further studies are required to elucidate the mechanisms behind the apelin-mediated increases in inflammation, as also deducing the role for endogenous apelin in asthma [16-19].

\section{Acknowledgment}

The authors thanks S Jamal Mustafa (West Virginia University) for his support.

\section{References}

1. Wu Y, Wang X, Zhou X, Cheng B, Li G, et al. (2017) Temporal expression of apelin/apelin receptor in ischemic stroke and its therapeutic potential. Front Mol Neurosci 10:1.

2. Chapman NA, Dupre DJ, Rainey JK (2014) The apelin receptor: physiology, pathology, cell signalling, and ligand modulation of a peptide-activated class A GPCR. Biochem Cell Biol 92(6): 431-440.

3. O'Dowd BF, Heiber M, Chan A, Heng HH, Tsui LC, et al. (1993) A human gene that shows identity with the geneen coding the angiotens inreceptor islocatedon chromosome 11. Gene 136(1-2): 355-360.

4. Boucher J, Masri B, Daviaud D, Gesta S, Guigne C, et al. (2005) Apelin, a newly identified adipokine up- regulated by insulin and obesity. Endocrinology 146(4): 1764-1771.

5. Hosoya M, Kawamata Y, Fukusumi S, Fujii R, Habata Y, et al. (2000) Molecular and functional characteristics of APJ. Tissue distribution of
mRNA and interaction with the endogenous ligand apelin. J Biol Chem 275(28): 21061-21067.

6. Siddiquee K, Hampton J, Khan S, Zadory D, Gleaves L, et al. (2011) Apelin protects against angiotensin II-induced cardiovascular fibrosis and decreases plasminogen activator inhibitor type-1 production. J Hypertens 29(4):724-731.

7. O'Carroll AM, Lolait SJ, Harris LE, Pope GR (2013) The apelin receptor APJ: journey from an orphan to a multifaceted regulator of homeostasis. J Endocrinol 219(1): R13-R35.

8. Habata Y, Fujii R, Hosoya M, Fukusumi S, Kawamata Y, et al. (1999) Apelin, the natural ligand of the orphan receptor APJ, is abundantly secreted in the colostrum. Biochim Biophys Acta 1452(1): 25-35.

9. Lee DK, Cheng R, Nguyen T, Fan T, Kariyawasam AP, et al. (2000) Characterization of apelin, the ligand for the APJ receptor. J Neurochem 74(1): 34- 41.

10. Messari ES, Iturrioz X, Fassot C, Mota DN, Roesch D, et al.(2004) Functional dissociation of apelin receptor signaling and endocytosis: implications for the effects of apelin on arterial blood pressure. Neurochem 90(6): 1290-1301.

11. Ishida J, Hashimoto T, Hashimoto Y, Nishiwaki S, Iguchi T, et al. (2004) Regulatory roles for APJ, a seven-transmembrane receptor related to angiotensin-type 1 receptor in blood pressure in vivo. J Biol Chem 279(25): 26274-26279.

12. Kawamata Y, Habata Y, Fukusumi S, Hosoya M, Fujii R, et al. (2001) Molecular properties of apelin: tissue distribution and receptor binding. Biochim Biophys Acta 1538(2-3): 162-171.

13. O'Carroll AM, Don AL, Lolait SJ (2003) APJ receptor mRNA expression in the rat hypothalamic paraventricular nucleus: regulation by stress and glucocorticoids. J Neuroendocrinol 15(11): 1095-1101.

14. Nadeem A, Ponnoth DS, Ansari HR, Batchelor TP, Dey RD, et al. (2009) A2A adenosine receptor deficiency leads to impaired tracheal relaxation via NADPH oxidase pathway in allergic mice. J Pharmacol Exp Ther 330(1): 99-108.

15. Ponnoth DS, Nadeem A, Tilley S, Mustafa SJ (2010) Involvement of A1 adenosine receptors in altered vascular responses and inflammation in an allergic mouse model of asthma. Am J Physiol Heart Circ Physiol 299(1): H81-H87.

16. Dray C, Debard C, Jager J, Disse E, Daviaud D (2010) Apelin and APJ regulation in adipose tissue and skeletal muscle of type 2 diabetic mice and humans. Am J Physiol Endocrinol Metab 298(6): E1161-E1169.

17. Masri B, Knibiehler B, Audigier Y (2005) Apelin signalling: a promising pathway from cloning to pharmacology. Cell Signal 17(4): 415-426.

18. O'Carroll AM, Lolait SJ, Howell GM (2006) Transcriptional regulation of the rat apelin receptor gene: promoter cloning and identification of an Sp1 site necessary for promoter activity. J Mol Endocrinol 36(1): 221235.

19. Wang G, Kundu R, Han S, Qi X, Englander EW, et al. (2009) Ontogeny of apelin and its receptor in the rodent gastrointestinal tract. Regul Pept 158(1-3): 32-39. 


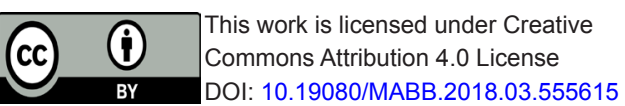

\section{Your next submission with Juniper Publishers will reach you the below assets}

- Quality Editorial service

- Swift Peer Review

- Reprints availability

- E-prints Service

- Manuscript Podcast for convenient understanding

- Global attainment for your research

- Manuscript accessibility in different formats

( Pdf, E-pub, Full Text, Audio)

- Unceasing customer service

Track the below URL for one-step submission https://juniperpublishers.com/online-submission.php 